\title{
Role of Media in Present Indian Social Scenario
}

\author{
Surinder kaur and Navjot kaur
}

"It may be true that the law can't make a man love me, but it can stop him from lynching me and I think that's pretty important." Laws are enacted for the protection of people and for the smooth functioning of the society. Laws provide a fair framework within which individuals and groups can choose their own values and codes, consistent with a similar liberty for others ${ }^{2}$. Hence laws both protect the integrity of different sects of society and also promote their harmonal existence. In the absence of law and order, society will turn into an unbearable chaos. However law acquires its life and performs its intended social functions through the process of implementation and enforcements, without which it has little meaning in any given society. ${ }^{3}$ Implementation of law is about 'law-in-action' and not 'law-in-the-books. ${ }^{4}$ Implementation part is the most difficult part for the rule of law. As Eugene Bardach notes,

It is hard enough to design public policies and programs that look good on paper. It is harder still to formulate them in words and slogans that resonate pleasingly in the ears of political leaders and constituencies to which they are responsive. And it is excruciatingly hard to implement them in a way that pleases anyone at all, including the supposed beneficiaries or clients. ${ }^{5}$

There is no doubt that the implementation of law is a complicated socio-legal process which involves many institutions and players. Judiciary and media are two independent institutions. Court, 'the capital of law's empire $^{6}$ is the first and last place where justice is fought for. Media is an indirect agent that assists police and judiciary in serving justice to suffering people by bringing perpetrators of law before public notice.

Media is the fourth pillar of democracy. It is a mirror of society and a powerful tool in implementing laws. Although the Indian constitution does not have an exclusive act defining the liberty of the press but it is evidently included in the freedom of speech and expression under the Article 19 (1) (a). Media, a derivative of word medium meaning carrier, reports news, provides information and analysis on issues and creates awareness among masses. The fundamental function of media, both print and mass media, is to inform people, educate them and guiding the society. Newspapers satisfies the queries of public by answering the questions of what, when, where, why, how the events happened and who are participants in various happenings. Media is easily accessible by all walks of people. It keeps people updated as information about everything and from everywhere is provided within seconds. Mark Twain rightly said

"There are only two forces that can carry light to all corners of the globe...the sun in the heavens and the associated press down here." 7

Media plays an active role in raising awareness on human rights, apart from other civil and political rights and helps in mobilizing people to recognize and protect human rights and bringing perpetrators to justice. By reporting and denouncing cases of human rights violations and other criminal cases and discussing punishments according to laws, media helps in bringing down the incidences of abuse and violation. Jianfu Chen notes,

" Implementation is often conceptualized as pressure politics (a system of pressure and counter pressure), a social and political phenomenon, an administrative control process,or an intergovernmental bargaining process. ${ }^{8}$

Media by exposing every crime, highlighting its far reaching effects, puts pressure on authorities to implement laws properly and to do justice to suffering people. Hence media roles as an enforcer of law. It acts as a watchdog and investigates and evaluates every incident in detail. By highlighting cases of violation and crime cases, media creates pressure on agencies to implement laws properly and give due punishments to the people involved in such criminal activities. Media offers a diagnostic and analytical platform for discussing the different causes of and solutions to, to the problem of improper implementation of law. Thereby forcing

\footnotetext{
${ }^{1}$ Martin Luther King Jr.'s quote available on www.goodreads.com/quotes/tag/law

${ }^{2}$ Martin J. Sandel, Liberalism and its Critics, quotes on law available on www.goodreads.com/quotes/tag/law

${ }^{3}$ Jianfu Chen et al. (eds.), Implementation of Law in the People's Republic of China (Netherland: Kluwer Law International, 2002) p. 2

${ }^{4}$ Ibid 1

${ }^{5}$ Eugene Bardach, The Implementation Game : What Happens after a Bill Becomes a Law ( Massachusetts/London : The MIT Press, 1977) p. 3

${ }^{6}$ Jianfu Chen et al. (eds.), Implementation of Law in the People's Republic of China (Netherland: Kluwer Law International, 2002$)$ p.8

${ }^{7}$ Mark Twain, quotes available on www.warc.com/pages/NewsAndOpinion/quotebank.aspx? category=media

${ }^{8}$ Jianfu Chen et al. (eds.), Implementation of Law in the People's Republic of China (Netherland: Kluwer Law International, 2002)p.2
} 
governments to adopt policies to raise the standard of actual implementation and to improve the functioning of the various law implementing/enforcing agencies. ${ }^{9}$

Media voices the hidden struggles of people for justice. It infuses new hope in people who have lost hopes of getting any justice. Media pinpoints the effect of delays and less punishments. Simply by reporting and discussing a crime event, media catalyzes the process of effective implementation of laws. Media played an important role in highlighting the cases such as Arushi murder case, Jessica Lal case. Media provided a high profile coverage of these crimes. These cases are being finalized due to the interference and pressure of media. Media is also an agent of change. It is because of media foregrounding the role of getting young adults in rape cases that the juvenile laws are reviewed and the age is now reduced to 16 from 18. Similarly sex determination tests were banned only when media brought its misuse to public notice.

Media has occupied a place of immense importance in today's society. Media is the difference between light and darkness. It removes the veil of darkness with the sun of information and right knowledge. By narrating the various rights and laws for the protection of rights in simple language, media acts as a mentor for laymen. It is now common fact that media is a beneficial agency in supporting or opposing any issue because it commands public opinion. As government is answerable to public, it can't ignore the irregularities brought to light by media. Hence as soon as media raises any issue, government tries to find its solution according to law. This is the power of free media in a democratic state. It brings a transparency in the working of administration. "Social media is a catalyst for the advancement of everyone's rights. It's where we're reminded that we're all human and all equal. It's where people can find and fight for a cause, global or local, popular or specialized, even when there are hundreds of miles between them" 10 There is now an increasing willingness among population to take their cases to court. ${ }^{11}$

Media employs the tools of discussion, opinion polls, debates, write ups to stimulate authorities for taking proper action. Hence media also holds the government and officials accountable before general public. "When there is information, there is enlightenment. When there is debate, there are solutions. When there is no sharing of power, no rule of law, no accountability, there is abuse, corruption, subjugation and indignation."12 By sharing information enlightens the common masses and puts a check on abuse or violation of laws.

Media does more than mere reporting news. It also monitors administration and keeps a check on corruption and bad administration. The fight against corruption has been largely fueled by the media. The scam cases like 2G spectrum, Adarsh society scam, CWG scam, all were brought to public notice and brought the politicians under scrunity.

It is not only that media highlights the weaknesses of improper implementation and resulting crimes, it also awares people for respecting and abiding by the laws of state, encourages people to pursue a lifestyle based on virtues of honesty and moral values. Media is the most vigilant sector towards the rule of law. Emphasizing the necessity of rule of law for stable and smooth society in citizens, media promotes a peaceful environment for the implementation of law.

It is through the operation and functioning of law in society that justice, fairness and human rights protection are achieved or abused. ${ }^{13}$ Laws in books serve no purpose. Implementation is life and breath of laws. Media is the guardian angel of the liberties that human race possesses. By imparting correct news, media applies a brake on the high-handedness of the sword of injustice. By arming common man with the weapons of knowledge and awareness, it helps in building a peaceful law governed just society.

\footnotetext{
${ }^{9}$ Jianfu Chen et al. (eds.), Implementation of Law in the People's Republic of China (Netherland: Kluwer Law International, 2002)p.4

${ }^{10}$ Queen Rania of Jordan's words on media on www.brainyquotes.com/quotes/keywords/media.html

${ }^{11}$ This refers to cases filed by students.

${ }_{12}$ Atifete Jahjaga 's quote on www.goodreads.com/quotes/tag/law

${ }^{13}$ Jianfu Chen et al. (eds.), Implementation of Law in the People's Republic of China (Netherland: Kluwer Law International, 2002)p. 2
} 